Article

\title{
The Seraphim above: Some Perspectives on the Theology of Orthodox Church Music
}

\section{Ivan Moody}

Centro de Estudos de Sociologia e Estética Musical (CESEM), Universidade Nova, Lisbon, FCSH, Av. de Berna, 26C, 1069-061 Lisboa, Portugal; E-Mail: ivanmoody@gmail.com;

Tel.: +351-21-790-8300 (ext. 1496)

Academic Editor: Edward Foley

Received: 5 March 2015 / Accepted: 24 March 2015 / Published: 2 April 2015

\begin{abstract}
Some outstanding contributions notwithstanding, much recent scholarship in Western European languages concerning art and the sacred has been quite prolific but has generally avoided discussion of specifically liturgical music, a particular problem when dealing with the sacred music of the Orthodox Church. The present discussion aims at establishing some bases for furthering this discussion, drawing not only on recent commentators but especially commentary on the question of liturgical singing by the Fathers of the Church.
\end{abstract}

Keywords: liturgical music; sacred music; Orthodox Church; Fathers of the Church

In recent years, a considerable number of books and articles in the English language dealing with art and the sacred from a Christian perspective have been published. Amongst the authors concerned with this theme are Jeremy Begbie [1], Daniel Chua [2], Richard Harries [3], Graham Howes [4], Catherine Pickstock [5], Philip Sherrard [6] and Patrick Sherry [7]. These publications have brought many useful and stimulating insights to the discussion of ways in which the arts may manifest the sacred and have served a crucial purpose in raising the level of that discussion both in artistic and theological terms.

Daniel Chua, for instance, in his essay "Music as the Mouthpiece of Theology" writes that,

"If music is an integral part of what it is to be human, then it ought to reflect something of the image of God in which we are made. If part of the imago Dei is the relationship of love that lies at the heart of the Trinity, then perhaps music can open up a way of thinking about 
how we relate to the world and to God in a manner where love, rather than reason, dominates. After all, music is inherently relational, both internally in the way its notes are put together and externally in the way in which it is used to communicate in everyday life.” ([2], p. 161).

This kind of observation might well give rise to a fascinating and deep theological analysis of music and its purpose in Christian life, but, in fact, none of the above-mentioned authors deal at any appreciable length with the question of the huge bodies of music actually intended for liturgical use, with the exception of that of J. S. Bach. There is discussion of the work of visual artists down the ages, from Duccio to Chagall, frequent mention of the icon, and analysis of the philosophical context for approaching the sacred in art and, especially in the work of Sherrard, the only Orthodox writer listed above, a genuine working towards the establishment of a mystagogy of artistic creation, but there is no real attempt to discover how, for example, Byzantine, Znamenny or Gregorian chant, Aquitainian polyphony, the Masses of Palestrina, the three-part polyphonic music of Georgia or the myriad composed settings of the Divine Liturgy from late 19th and early 20th century Russia, to take a few examples, might embody or transmit the sacred in their respective liturgical contexts. Chua, indeed, is quite clear that in discussing "music as a mouthpiece for theology", he wishes theology to "articulate the difference while engaging with the modern and postmodern world" ([2], p. 161), and while one might similarly wish liturgical chant to engage with the modern and postmodern world, if it is to do so, it must first be understood as music transmitting theology, which is what it was designed to do.

While, at the same time, magisterial research into this area has been undertaken by authors directly concerned with the praxis of the liturgy, such as Edward Foley, Anthony Ruff and Joseph Swain, and while there is naturally material available in the languages of countries of Orthodox tradition $[8,9]$ (though even this does not strike one as abundant), the only substantial pieces of writing in a Western European language dealing at any length with the subject in a specifically Orthodox context of which the present writer is aware is the remarkable study by Hilkka Seppälä [10], which offers a strong Biblical and patristic grounding for the study of the subject, but which does not enter into questions of a practical nature (i.e., specifically those of musical style), and Nicolas Lossky's monograph from 2003 [11], which does. Even here, however, in a work whose first chapter is entitled "Music and Nicaea II", the author feels obliged to begin with conciliar definitions and regulations regarding icons, and then to explain why he has done so, before moving on to "Liturgy and Theology". Only afterwards, in his third chapter, does he discuss "Music and Theology", which contains valuable, if general, insights, and then proceeds to a discussion of the possibilities and limitations of the situation as he understood it in France and elsewhere at the time of writing. Ironically, his final chapter is entitled "Instead of a conclusion: Silence" and, apart from Lossky and a very few others excepted, it is, within the Western traditions of theological and philosophical (and aesthetic) discussion, silence that we find on this topic.

This lacuna in the literature is, I consider, curious. It is as though musical works created outside the liturgical context might offer more material for examination, in that they "transcend" in some way the category of music simply by being concerned with matters theological, whereas a corpus of chant written for liturgical use is merely functional. The writer Jeanette Wintersen perhaps comes close to an answer when she says, with regard to paintings, 
"Canonising pictures is one way of killing them. When the sense of familiarity becomes too great, history, popularity, association, all crowd in between the viewer and the picture and block it out. Not only pictures suffer like this, all the arts suffer like this." ([12], p. 12).

And one can see the justice of this observation. But yet again, she is discussing categories of art that, while they may include the sacred, also include much that is outside it - she is discussing public perception of art qua art, not "functional" art such as is the case with icons or liturgical chant.

Can such a view, then, possibly be correct? Could it really be the case that concert music might speak more directly of the sacred than music designed specifically for the words of the liturgy, sung in liturgical time and space? I suggest that while in one sense this could be true (and the success of paraliturgical music such as that by the late Sir John Tavener, Arvo Pärt, James MacMillan and others could be seen as supporting such a view), given modern (or postmodern) man's general dissociation from the sacred and frequent embarrassment at any expression of it, and the possibility of hiding the sacred, so to speak, within the philosophical framework of a concert work, it cannot possibly be true as a general rule. If it were so, liturgical music would long ago have been seen to be of no spiritual use and the Church would scarcely have become so involved in the question of precisely what that music should be, whether through the decrees of an Ecumenical Council, say, local edicts, or such councils as those of Trent and Vatican II. As it is, the ecclesial communities that employ a given corpus of chant in their liturgical lives are numerous, and the discussion surrounding the propriety of one kind of liturgical music or another so vigorous, that it is clear that here is an area-one might say the essential area-of sacred music that cries out for such analysis and discussion but has not, generally speaking, received it.

It seems therefore appropriate to quote at this point from the introduction to a remarkable course on the theology of church music devised by Archpriest Michael Fortounatto, at present available only in French but in the process of translation by the present author. He begins thus:

"Liturgical music, like the icon, is only found in actual liturgy and in the Christian home, that is, the manifestation of the Kingdom in the church. Its impact on the faithful is immediate. It does not seem to be a mediator between the sung word and its reception by the listener. Music that resonates may thus be compared to a stained glass window which filters and colours, but does not halt, the daylight. Its emotional impact is sometimes considerable.

One should not be mistaken, however. Music is the work of mankind, and as such, it can also be subject to the fall, be made opaque, ugly and become a screen. We shall discuss later the conditions of its transparency. But, a priori, at its birth and in the perfection of its creation by an omnipotent God, music is pure by definition, even though perfectible in the use to which it is put by man." ([13], p. 1).

Immediately, we have here a potential definition of what liturgical music is, and therefore of the way in which it differs from any other kind of music, whether any other kind of music may interact with theology or not.

"Music as a physical phenomenon", continues Fr Michael, "unlike the icon, disappears after having sounded. Written scores, recordings on disc, concerts, are only mirrors that we use for its study. In 
analysis, the researcher depends on this physical witness, and above all on tradition, that is in the memory he retains of the services as a whole, and of which he is the witness and inheritor" ([13], p. 1).

While the comparison of physical phenomena is not new, the author here touches on another crucial aspect of liturgical music, that of the role of memory and, by extension, tradition. Though there is some parallel in ethnomusicology for this, the sense in which the term "tradition" is understood here is, in fact, in other than strictly musical terms, very different, and simultaneously remarkably vivifying and remarkably dangerous-vivifying because it allows the eternal renewal of the possibility of creation and spiritual life, and dangerous because that very same possibility can lead to fossilization or spiritual death.

The heart of the matter is in what Fr Michael says next:

"The theological study of chant in its organic union with the Biblical and patristic word passes initially through an intuitive path with the aim of tracing the axes of theological examination, hypotheses which must subsequently be confirmed by a more formal analysis with the aid of precise musicological criteria established at the outset. The theological character of liturgical chant obviously derives from its intimate association with the sung word, just as the word takes its theological character from the thought that expresses the Orthodox faith. Everything, in creation, may become a vehicle for theology; man and the universe are called to be transfigured." ([13], p. 1).

It is, nevertheless, a matter of historical fact that the Church has not agreed in all places and at all times about what kind of music genuinely has a "theological character" [14]. The Fathers of the Church are clear, in general, about what music should not be, and about what music is capable of, but it remains the case that discerning with any precision what kind of music might meet with Patristic approval is not always easy. In that case, how might we begin to find, or construct a theology of liturgical chant? What might constitute such a theology? Why, indeed, is it necessary?

To answer the last question first, such a theology is necessary if we believe that the liturgy is a place, a time, of encounter with Christ, if we believe that it is in fact the Kingdom of God manifest upon earth in which the faithful participate fully, as "kings, priests and prophets in a new creation" ([15], p. 38). Such a liturgy clearly cannot be simply a collection of personal impressions, personal interpretations - this is precisely why the fourth-century Council of Laodicea, in its 59th canon, had to rule that 'privately composed psalms' (idiotikoi psalmoi) might no longer be written-but must instead be subject to the Church's accumulated wisdom ("Tradition") as expressed in the Old and New Testaments and their interpretation through the Church, explained and set down in the canons of the Ecumenical and other Councils. Such a view necessarily implied the regulation of music. If the psalms and hymns officially approved by the Church as transmitting authentic dogma, as revealing Christ and the history of salvation to man, are to be sung, to what music should they be sung? How can that music be regulated so that it is appropriate to the theological weight of the words it is setting? As Nicholas Lossky put it,

"If one takes seriously the consequences of the Incarnation, 'real and not imaginary, of the Word of God', as stated in the definition of Nicaea II, then all liturgical art must reflect the reality of this new creation - or, at the very least, must not contradict it. Indeed, the definition of Nicaea II speaks of art 'which is in accordance with the narrative of the 
Gospel' (...) Liturgical art should of necessity participate in this preaching (of the Gospel), be at service, be one with it, be in harmony with it" ([15], p. 39).

Nobody today, of course, can come to a conclusion as to how the music of the Church first sounded or what its guiding principles were beyond the very little mentioned in the New Testament. The earliest documentation we have is that of the Fathers of the Church and the prescriptions of the Councils, and to these we shall return in detail.

Secondly, returning to the two earlier questions but also in continuation of the response to the third, the first places to seek for sources of a theology of chant are obviously the earliest. If we leave aside references in the Psalms, the Book of Revelation, Acts and the tantalizing but bare references in the

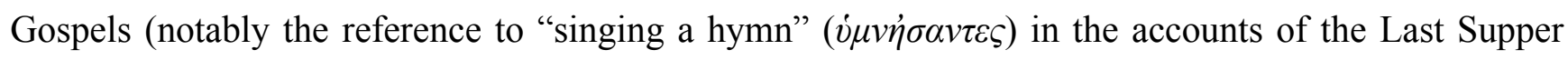
according Sts. Matthew and Mark), and St Paul's injunction to sing "psalms, hymns and spiritual

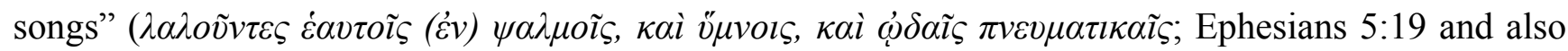
Colossians 3:16), it is clear that we need to have recourse to the writings of the early Church Fathers. Patristic writings on music rarely give any genuinely musical clues, discussing as they do the nature of the allusions in the Psalms to the instruments of now-defunct Temple liturgy, and the moral value of music. St Basil's Homily on the First Psalm, for example, is barely related to anything that we might now recognize as liturgical music; it gives, rather, the impression of a discussion of some kind of para-liturgical music, accompanied by a psaltery - the discussion is, in the end, about the text rather than any potentially musical realization of it. St John Chrysostom talks more specifically about music and its spiritual effects - whether positive or negative - but his musical discussion is thoroughly of the classical Greek type, and references to the singing of psalms have more to do with home churches, showing no concern with anything resembling what we would now describe as Christian liturgy.

However, while patristic commentary may not tell us anything about the sound of the music to be heard at the time, the image of song is so pervasive, and so frequently used in connection with moral and spiritual commentary that it is clear that any attempt at constructing a theology of chant must begin with these writings. Bearing that in mind, I recall here Fr Michael Fortounatto's observation that, “...chant has its existence only in prayer addressed to God in all places of His dominion; in this it expresses the praise and supplication of the believer, searching for the divine presence; in blessing God, man aspires to holiness and draws near to his Creator; in this sense, the chant that accompanies prayer may be qualified as HOLY" ([13], p. 2).

In the search for corroboration of this, one might begin with the bishop and martyr St Methodios of Olympus (d. 311). His Symposium, or On Virginity (Symposion e peri hagneias) is modelled on Plato's Symposium, ten virgins discoursing at a feast on the virtues of Christian chastity. The text is full of natural and musical images, and it ends with a metrical hymn in honour of Christ the Bridegroom. In the third discourse, Thalia gives an interpretation of Psalm 40, a psalm replete with images of song. She says,

"Now, those who sing the Gospel to senseless people seem to sing the Lord's song in a strange land, of which Christ is not the husbandman; but those who have put on and shone in the most pure and bright, and mingled and pious and becoming, ornament of virginity, and are found barren and unproductive of unsettled and grievous passions, do not sing the song in a strange land; because they are not borne thither by their hopes, nor do they stick 
fast in the lusts of their mortal bodies, nor do they take a low view of the meaning of the commandments, but well and nobly, with a lofty disposition, they have regard to the promises which are above, thirsting for heaven as a congenial abode, whence God, approving their dispositions, promises with an oath to give them choice honours, appointing and establishing them 'above His chief joy'.” [16].

Allegorical though the commentary be, it is striking in its insistence of the Gospel being not only "sung", but sung well-with a "lofty disposition". Such an allegory would, of course, be impossible without the actual existence of singing that was considered good and uplifting.

St Gregory the Theologian (329-395), discusses the relationship between the Holy Spirit and singing. In describing the necessity of God's providence, he says that "the choir would stop... without its conductor" ([17], p. 53), and the Apostolic Constitutions, from the late 4th century, speak of the Seraphim singing with the Cherubim, the angels singing in yet another way and human beings using yet another means of expression: "(...) and the Seraphim, with the six-winged Cherubim, singing with unceasing voices the triumphal hymn, cry out: 'Holy, holy, holy is the Lord Sabaoth. His brightness fills the whole earth", and the other orders of angels cry: "Blessed is the glory of the Lord from His place", while Israel, the Church on earth, following the example of the heavenly powers, sings "with brave heart and eager mind (2 Macc. 1:3)" ([10], p. 53; [18], cols. 1987, 1029). Indeed, Hilkka Seppälä, who devotes an entire chapter to angels as teachers of church singing in her study, points out that the Seraphim are "almost always presented as the most important among the singing groups (of the ranks of angels)" ([10], p. 57) and St Basil the Great (330-379), in On the Holy Spirit, points out

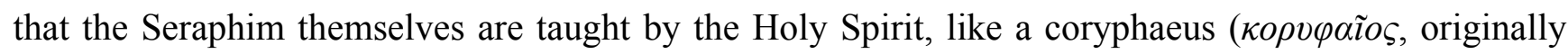
the leader of the chorus in Attic drama), and we in turn imitate the celestial liturgy on earth, with the thrice-holy hymn:

"For [life] so to abide [without the Spirit] were as likely as that an army should maintain its discipline in the absence of its commander, or a chorus its harmony without the guidance of the coryphaeus. How could the Seraphim cry 'Holy, Holy, Holy', were they not taught by the Spirit how often true religion requires them to lift their voice in this ascription of glory? Do 'all His angels' and 'all His hosts' praise God?” [19].

St Ephrem the Syrian (d. 373), prolific author of hymns, was fully aware of the seductive effect of pagan music, and effectively baptized it by copying its rhythms. He wrote extensively of the effect of psalmody on the soul and was in no doubt of its power. In his On Psalmody, he says the following:

"But let us (...) speak of repentance and the coming judgement. For we should always meditate on these things, because the day of the Lord is coming like a thief in the night. Therefore by night and day, look to your last hour and meditate on the law of the Lord day and night. Say many things to God and few to humans. If you stretch out your hand to work, let your mouth sing psalms and your mind pray. Let psalmody be continually on your mouth, for when God is being named he puts the demons to flight and sanctifies the singer.

Psalmody is calm of soul, author of peace. Psalmody is convenor of friendship, union of the separated, reconciliation of enemies. Psalmody attracts the help of the Angels, is a 
weapon in night-time fears, repose of the day's toils, safety for infants, adornment for the old, consolation for the elderly, most fitting embellishment for women. It make deserts into homes, market places sober. It is the ABC for beginners, progress for the more advanced, confirmation for the perfect, the voice of the Church. It makes festivals radiant; it creates mourning that is in accordance with God, for psalmody draws tears even from a heart of stone. Psalmody is the work of the Angels, the commonwealth of heaven, spiritual incense. Psalmody is enlightenment of souls, sanctification of bodies.

Let us, brethren, never stop making psalmody our meditation, both at home and on the road, both sleeping and waking, speaking to ourselves in psalms and hymns and spiritual songs. Psalmody is the joy of those who love God. It banishes idle chatter, brings laughter to an end, reminds us of the judgement, rouses the soul towards God, joins the choir of the Angels. Where there is psalmody with compunction, there God is, with the Angels. Where the songs of the opponent are, there is God's wrath, and 'woe!' is the reward of laughter. Where sacred books and readings are, there are the joy of the just and the salvation of the listeners. Where there are harps and dances, there is the darkening of men and women, and a festival of the Devil.

O the wicked cunning and contrivance of the Devil! How he trips each one through craft, and deceives them and persuades them to do evil as though it were good! Today they decide to chant, tomorrow they dance with enthusiasm. Today they are Christians, tomorrow heathens. Today of good repute, tomorrow pagans. Today servants of Christ, tomorrow rebels against God. Do not be deceived. No one can be servant of two lords, as it is written. You cannot serve God and dance with the Devil." [20].

The sheer power of music is clearly recognized in St Ephrem's words; and if psalmody is "the work of the angels", it is obvious that it must be regulated in such a way that on man's lips it may indeed become angelic. But one might also call to mind here Fr Michael Fortounatto's point that “...one of the reasons for the existence of the liturgical art that is chant is the teaching of the faith, the Christian mission; this is why liturgical chant must be qualified as APOSTOLIC" ([13], p. 2): St Ephrem's activity consisted precisely in the teaching of the faith, the Christian faith, and was therefore nothing if not apostolic.

St John Chrysostom also described the angelic singing, in the following words:

"How do I understand that words proceed into deeds? (...) from the fact that imitating the angelic choir, and endless hymnology is offered to God (...). Above, the armies of angels praise while below the people are standing in the choir of the church and imitating their praise. The Seraphim above cry the thrice-holy hymn and the people below raise the same hymn." [21].

St Basil reinforces the point that singers on earth should imitate the singing of the angels, and emphasizes its very concrete results:

"What is more blessed than to imitate the chorus of the angels here on earth; to arise for prayer at the very break of day and honour the Creator with hymns and songs; and then 
when the sun shines brightly to turn to our work, and, with prayer as an ever-present companion, to season our tasks with hymns as if with salt? For the consolation of hymns favours the soul with a state of happiness and freedom from care." [22].

Psalmody is viewed, then, as a very direct, physical means of spiritual purification, as a path to a state of blessedness. St Athanasios the Great wrote that through singing psalms, "the turbulence and roughness and disorder in the soul are smoothed away and sadness is overcome" ([23], p. 100). He also notes that those who sing psalmody properly "psalmodize not only with their tongue, but also with their mind, and benefit greatly not only themselves but also those who desire to listen to them. Thus the blessed David, chanting in this way to Saul, himself pleased God, and banished the turbulent and mad passion of Saul, and rendered his soul calm" ([23], p. 100). Similarly, Evagrios of Pontos notes that "Psalmody, long-suffering and compassion stop the agitation of anger" ([24], p. 34).

It is clear, however, that imitation of angelic song, the kind of chanting capable of putting the passions to sleep and stilling the intemperance of the body, cannot be lightly undertaken: such chanting requires attentiveness and humility. The 75th Canon of the Synod in Trullo (691-692) states that "those whose office it is to chant in churches...offer the psalmody to God, Who is the observer of secrets, with great attention and contrition". St John Chrysostom, in reference to St Paul's injunction to sing to God "with psalms, with hymns, with spiritual songs" (Ephesians 5:19 and Colossians 3:16), also insists that such singing is to be done with spiritual attentiveness, "For this constitutes singing to God-the other is merely singing to the air" ([21], p. 101).

Such instructions make clear the kind of attitude necessary for the prayerful rendition of psalmody, and given its importance in the understanding of these Church Fathers, it is obvious that its regulation and prescription would become a matter to be dealt with by the Councils of the Church. Here are the prescriptions from Canon LXXV of the Council in Trullo (Quinisext), held in 692:

"We will that those whose office it is to sing in the churches do not use undisciplined vociferations, nor force nature to shouting, nor adopt any of those modes which are incongruous and unsuitable for the church: but that they offer the psalmody to God, who is the observer of secrets, with great attention and compunction. For the Sacred Oracle taught that the Sons of Israel were to be pious." ([25], p. 398).

These make it evident that a correct spiritual disposition is necessary for the correct chanting of psalms and hymns. What is not so evident, however, is precisely what might have constituted at this period "undisciplined vociferations" or "shouting". The entire question of style, of what might be considered liturgically appropriate in any given time and place, is one that complicates the interpretation of such prescriptions in no uncertain manner. In this context, it is instructive to read what Pope Emeritus Benedict XVI wrote in an extremely perceptive essay on the problems of liturgical music. He said that,

"...the Fathers of the Church (...) regarded the musical riches of the Old Testament and Graeco-Roman culture as a part of the sensible, material world which was to be overcome in the spiritual world of Christianity. They understood spiritualisation to mean dematerialisation and hence understood it in a manner which more or less borders on iconoclasm. That is 
theology's historical mortgage in the question of ecclesiastical art, and it is a mortgage which comes to the fore over and over again during the course of history." [26].

While it is acknowledged in his paper that the continuation of this story is far from as simple as this statement regarding the Fathers of the Church would appear to imply, the then-Cardinal Ratzinger nevertheless places those Fathers, in such a statement, within a philosophical framework that has little to do with what is today considered to be Orthodox tradition. It is clearly possible to regard the new Christian musical world, as it were, as one that had overcome the "sensible, material world", but the reinvention of music at the hands of St Ephrem the Syrian would suffice as an example to contradict any claim of near-iconoclasm. It is precisely the Fathers' understanding of the Incarnation, and therefore the necessity for incarnate art and incarnate music, that militates against such an assertion. Rather, it is a recognition of the reality of the negative aspects of the physical realm that lead the Fathers to propose, as did St John Chrysostom, that

"Nothing so uplifts the mind, giving it wings and freeing it from the earth, releasing it from the prison of the body, affecting it with love of wisdom, and causing it to scorn all things pertaining to this life, as modulated melody and the divine chant composed of number" ([27], II:13).

It is also fundamental to view such statements against the background of pagan music, and the Fathers' perception of this as an accompaniment to debauchery and licentiousness. We can thus understand what underlies the observation of Bishop Jacob of Serugh when he said of St Ephrem the Syrian that he

"saw that women were silent from praise

and in his wisdom he decided it was right that they should sing out;

so just as Moses gave timbrels to the young girls,

thus did this discerning man compose hymns for virgins.

As he stood among the sisters it was his delight

to stir these chaste women into songs of praise;

he was like an eagle perched among the doves

as he taught them to sing new songs of praise with pure utterance" ([28], p. 234).

It is clear from this that "dematerialization" was not the object the "new songs of praise", sung with "pure utterance". The physicality of those new songs was intended to combat the physicality of the songs of the pagans. An observation by Joseph McKinnon is relevant here: in speaking of early Egyptian monasticism, he notes that Palladius (d. 425), in the Lausiac History, "gives us a hint of what the private weekday office might have been like at Nitria in Lower Egypt: 'one who stands there at about the ninth hour can hear the psalmody issuing forth from each cell, so that he imagines himself to be high above, in paradise"” ([29], p. 507). McKinnon then goes on to say, however, that, "Of course, what sounded heavenly to Palladius might, by narrowly musical standards, have been cacophonous, with each monk chanting in his own way and in his own time. But even the most secularly inclined of moderns should be able to imagine themselves stirred by the religious resonance of such a scene; and, more to the point, the chanting of certain individual monks might itself have manifested a kind of unselfconscious beauty" ([29], p. 507). 
This is remarkable on two counts: firstly, because it recognizes the absolutely incarnate quality of the singing - a religious "cacophony" could be nothing other than incarnate, a physical experience-and secondly, because it introduces the idea of "unselfconscious beauty", a formulation that summarizes magnificently the way in which an incarnate liturgical singing must surely be expected to sound.

Quite specific and unusually direct instruction concerning singing may be seen, rather earlier, in the writings of Niceta of Remesiana. Niceta was appointed bishop of Remesiana (now Bela Palanka, Serbia) in about 370. In his "On the Benefit of Psalmody", described by its translator James McKinnon as "a remarkable summary of the early Christian doctrine on ecclesiastical song", Niceta refers to the Canticle of the Three Youths in the Furnace, as found in the Book of Daniel, and observes:

"You have it here on biblical authority that the three praised the Lord together 'as if from one voice', just as all of us must exhibit the same intention and the same sounding melody as if from a single voice. Those, however, who are not able to blend and adapt themselves to the others, ought better to sing in a subdued voice than to create a great clamour; and thus will they fulfil their liturgical obligation and avoid disrupting the singing community. For it is not given to all to possess a supple and pleasant voice" ([27), p. 21).

Through apophatic theology, the inadequacy of the human intellect and human language to express the fullness of truth is continually proclaimed, and the writings of such as Nikiphoros the Hesychast bear (paradoxically eloquent) witness to this ([30]). It is precisely "human language" that is transcended in the extraordinarily elabo rate chants composed by St John Koukouzeles for the all-night vigils at the Great Lavra on Mount Athos, which employ a wide vocal range, dramatic leaps, dazzling melodic sequences and, crucially, the wordless vocalizing that is the kratema, characterized by Alexander Lingas as "institutionalized pentecostalism" ([31], p. 163). ${ }^{1}$ Words, liturgically authorized and doctrinally authoritative though they may be, have, in effect, given way to awe-struck, interior silence.

When we turn to later theological approaches on the question of the theology of sacred music, we come up against the twin difficulties of linguistic barriers and the calamity of the advent of communism. These meant that the wave of spiritual revival, including the rediscovery of Byzantine icon styles and earlier repertories of monophonic chant, evident at the end of the 19th century and beginning of the 20th, particularly in Russia, did not have an immediate opportunity to make an impact in the West. In addition, the radical reforms enacted in the Roman Catholic Church after the Second Vatican Council meant that, in any case, there would have been little point of contact with Orthodox liturgical aesthetics.

The subject of liturgical music, its aesthetics and its theology, was, nevertheless, one of lively debate in 19th century Russia. From one of the Letters to a Beginner by the Abbess Thaisia of Leushino, we can gain an eminently practical view of what was expected of the church singer. She frames her advice with the words: "What a wonderful and great gift-the gift of a voice and the ability to sing! They were given to us for this, that with them we might both glorify the Lord ourselves, and

1 The term kratema comes from kratein, "to hold", and refers to the holding, or prolongation, of a liturgical chant melody. The term terirem is also found, referring to the nonsense syllables "te-ri-rem" that were the text of the kratemata, whether as independent compositions or sections of other chants. 
incite others to do the same" ([32], p. 56). ${ }^{2}$ The letter continues to expound in depth upon the nature of singing:

"The singing of the chanter passes over to the hearts of those who are praying; if the singing proceeds from the heart, it meets the heart of the listener and so influences him that it is able to rouse him to prayer, to incite reverence even in those minutes when the heart itself is distracted and hard. Often it happens that those who enter the church without any eagerness toward prayer, from compulsion or from propriety, begin to pray fervently and tearfully, and leave the church in quite another frame of mind, in a spirit of tender feeling and repentance. Such a revival is produced in them by the magnificent service and fine singing. And, conversely, often it happens that those who enter the church with the intention to pray from the soul, to pour out before the Lord their sorrowful soul, when they hear scattered, careless singing and reading, themselves little by little become distracted, and instead of profit they find harm, they receive no consolation and, having been tempted by the conduct of the singers, involuntarily fall into the sin of condemnation.

Strive with all your strength to concentrate attentively on the words which you pronounce; pronounce them in such a manner that they come from the depth of your soul, which is singing together with your lips. Then the sounds of the vivifying current of your hymn will pour into the souls of those who hear them, and these souls, being raised from the earthly to the heavenly, having laid aside all earthly care, will receive the King of Glory Who is borne in triumph by the Angelic Hosts." ([32], p. 57).

Such an approach is clearly deeply imbued with patristic wisdom, in its reiteration of the idea that the singer's disposition and attentiveness affects the sound emitted, the psalmodizing, and the idea that chanting is a preparation for entering into the holy, for the reception of Christ.

The veneration of earlier repertoire, at least in its spirit, is seen in the following comments on the music of Kastal'sky by the critic Ivan Lipaev in 1898:

"In church music (Kastal'sky) is a type of Vasnetsov. One would like to hear his arrangements and compositions under the arches of the Kievan St Vladimir Cathedral, so permeated are they with incorporeity and asceticism, so dissimilar are they to the extravagance of a lone individual, sounding more like an echo of a composition by an entire people...Listening to his works, it seems at times that they have burst into this world of their own accord, without will and effort on the composer's part. It appears that (Kastal'sky) has wholly mastered the inner essence of ancient singing; his instinct has not misled him." ([33], p. 221). ${ }^{3}$

In the light of this, it is interesting to note what Kastal'sky himself had to say about the composition of church music, in an article entitled "My Musical Career and My Thoughts on Church Music":

\footnotetext{
I am very grateful to Sydney Freedman for drawing my attention to this source.

3 The reference to Vasnetsov is to Viktor Mikhailovich Vasnetsov (1848-1926), a painter who synthesized modern painting techniques with nationalistic subjects and iconography, and painted most of the frescos and icons of the neo-Byzantine St Vladimir Cathedral in Kiev.
} 
"And style?...Our original church tunes when laid out chorally lose all their individuality; what distinction they have when sung in unison as they were by the old-believers, and how insipid they are in the conventional four-part arrangements of our classics, on which we have prided ourselves for nearly a hundred years: it is essential but... spurious." ([34], pp. 237-38).

"The future of our creative work for the Church can also be merely surmised, but I feel what its real task should be. I am convinced that it lies in the idealisation of authentic church melodies, the transformation of them into something musically elevated, mighty in its expressiveness and near to the Russian heart in its typically national quality. (...) I should like to have music which could be heard nowhere except in a church, and which would be as distinct from secular music as church vestments are from the dress of the laity." ([34], p. 245).

It is quite clear in such writing that, though the intention is to return to "indigenous church melodies", and in spite of Lipaev's characterization of Kastal'sky's style as incorporeal and ascetic, the motivation is emotional and nationalistic, rather than grounded in liturgical theology.

In the later 20th Century, however, as part of a wider revival of theological writing, by Orthodox authors from various countries, including Greece, Romania, Russia, France, Great Britain and the USA, and aided by serious attempts at systematic translation into western languages (notably French, English, German and Finnish), it has become evident that not only has an Orthodox understanding of theology and the way in which it is transmitted through the liturgical arts never lost its depth or its roots in Church tradition, but that it is at the same time able to adapt to new circumstances, and has become, on that account, of great interest to Western theologians. To return to the words of Fr Michael Fortounatto for a final time, "Liturgical chant is the creation of the Church in each local historical tradition. And since the Church is built up of a body around its bishop in every place of its incarnation, chant may thus also be said to be CATHOLIC in its constituent elements, in the image of the Church" ([13], p. 2).

However, while writing on icons and the theology of icons, in the wake of the contributions of such authors as Vladimir Lossky, Leonid Ouspensky and Paul Evdokimov has blossomed, recent commentary on the theology of Orthodox chant has, as I noted at the beginning of this essay, proved far more difficult to come by; it is significant, for example, that the Cambridge Companion to Orthodox Christian Theology (2008) makes not a single mention of music. Theology has, so to speak, been left to the practitioners of church music, whose objective is to sing with "the seraphim above", and while this is as it should be in that music is an incarnate expression of theology, there is no reason that the Church should be simultaneously bereft of commentary thereon; indeed, this is essential in that an understanding of the theology of church music should be a prerequisite for any composer working in this field. Indeed, the hugely increased availability of Orthodox church music throughout the world, the constant and continuing discussions concerning the most appropriate styles of music for worship within the Orthodox Church itself, and the vigorous outpouring of new liturgical music from composers whose views on this vary enormously, make the acquisition of such an understanding a matter of urgency. 
With the work of the scholars from outside Orthodox tradition I mentioned at the beginning of this article, such as Chua, Harries and Sherry, to which one might add substantial books by John Dillenberger [35] and Richard Viladesau [36], the small amount of writing that has come from inside the Orthodox tradition (Philip Sherrard, Hilkka Seppälä, Nicolas Lossky and, very particularly, Fr Michael Fortounatto), and the vast treasury of material left to us by the Fathers of the Church, it is with increasing optimism that one may look forward to Orthodoxy reclaiming this ground and reflecting in genuine depth on the theological richness of its various traditions of sacred music.

\section{Conflicts of Interest}

The author declares no conflict of interest.

\section{References}

1. Jeremy Begbie. "Created Beauty: The Witness of J. S. Bach.” In Resonant Witness. Conversations between Music and Theology. Edited by Jeremy S. Begbie and Steven R. Guthrie. Grand Rapids: Eerdmans, 2011, pp. 83-108.

2. Daniel Chua. "Music as the Mouthpiece of Theology." In Resonant Witness. Conversations between Music and Theology. Edited by Jeremy S. Begbie and Steven R. Guthrie. Grand Rapids: Eerdmans, 2011, pp. 137-60.

3. Richard Harries. Art and the Beauty of God. London: Continuum, 1993.

4. Graham Howes. The Art of the Sacred. London: I.B. Tauris, 2007.

5. Catherine Pickstock. "Quasi una Sonata: Modernism, Postmodernism, Religion and Music." In Resonant Witness. Conversations between Music and Theology. Edited by Jeremy S. Begbie and Steven R. Guthrie. Grand Rapids: Eerdmans, 2011, pp. 190-211.

6. Philip Sherrard. The Sacred in Life and Art. Ipswich: Golgonooza Press, 1990.

7. Patrick Sherry. Spirit and Beauty, 2nd ed. London: SCM Press, 2002.

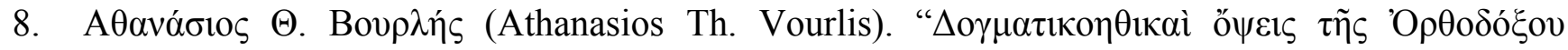

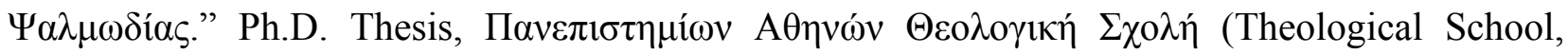
University of Athens), 1994.

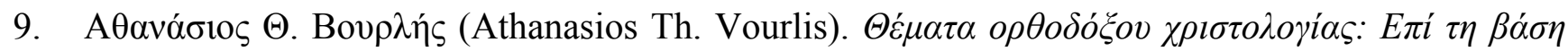

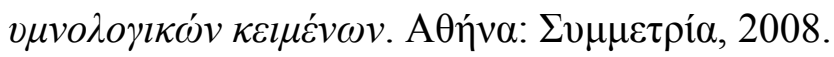

10. Hilkka Seppälä. The Song of Fire and Clay. Joensuu: University of Joensuu, 2005.

11. Nicholas Lossky. Essai sur une Théologie de la Musique Liturgique: Perspective Orthodoxe. Paris: Cerf, 2003.

12. Jeanette Winterson. Art Objects. London: Jonathan Cape, 1995.

13. Michel Fortounatto. "Cours de Musicologie.” Available online: http://www.musique-orthodoxe.fr/ page-4theologie.html (accessed on 7 January 2015).

14. Ivan Moody. "The Idea of Canonicity in Orthodox Liturgical Art." In Composing and Chanting in the Orthodox Church: Proceedings of the Second International Conference on Orthodox Liturgical Music. Edited by Ivan Moody and Maria Takala-Roszczenko. Joensuu: ISOCM/University of Joensuu, 2009, pp. 337-42. 
15. Nicholas Lossky. "Liturgy and Liturgical Art from an Ecumenical Perspective." Sourozh 36 (1989): 36-41.

16. Methodios of Olympus. "The Banquet or On Virginity." In Patrologia Graeca. Edited by Jacques Paul Migne. Paris: Imprimerie Catholique, 1857. Available online: http://books.google.com/ books?id=D-dkJipaJfMC\&pg $=$ PA18\&source $=$ gbs_toc_r\&cad $=2 \# \mathrm{v}=$ onepage \&q\&f $=$ false (accessed on 7 January 2015). Translation available online: http://www.tertullian.org/fathers2/ ANF-06/anf06-112.htm\#P4956_1494425 (accessed on 7 January 2015).

17. Gregory of Nazianzus. On God and Man: The Theological Poetry of St Gregory Nazianzus. Translated by Peter Gilbert. Crestwood: St Vladimir's Seminary Press, 1991.

18. Anonymous. "Apostolic Constitutions." In Patrologia Graeca. Edited by Jacques Paul Migne. Paris: Imprimerie Catholique, 1857. Available online: http://books.google.com/books?id=To_ YAAAAMAAJ\&printsec $=$ frontcover\&source $=\mathrm{gbs} \_g e \_s u m m a r y \_r \& c a d=0 \# \mathrm{v}=$ onepage $\& \mathrm{q} \& \mathrm{f}=\mathrm{false}$ (accessed on 7 January 2015).

19. Basil the Great. "On the Holy Spirit." Translated by Blomfield Jackson. Available online: http://www.myriobiblos.gr/texts/english/basil_spiritu_16.html (accessed on 7 January 2015).

20. Ephrem the Syrian. "Three Short Discourses, No. 2. On Psalmody." Translated by Ephrem Lash. Available online: http://www.anastasis.org.uk/3disc.html (accessed on 7 January 2015).

21. John Chrysostom. "Homily on Ozias." In Patrologia Graeca. Edited by Jacques Paul Migne. Paris: Migne, 1862. Available online: http://books.google.com/books?id=DG5FdYQEI20C\& printsec $=$ frontcover\&source $=$ gbs_ge_summary_r\&cad $=0 \# \mathrm{v}=$ onepage $\& \mathrm{q} \& \mathrm{f}=$ false $(\operatorname{accessed}$ on 7 January 2015).

22. Basil the Great. "Letter II: 2." In Music in Early Christian Literature. Edited by James McKinnon. Cambridge: Cambridge University Press, 1989, p. 68.

23. Constantine Cavarnos. Byzantine Thought and Art. Belmont: Institute for Byzantine and Modern Greek Studies, 1974.

24. Evagrios (the Solitary) of Pontos. "Outline Teaching on Asceticism and Stillness in the Solitary Life.” In The Philokalia. Translated and Edited by G.E.H. Palmer, Philip Sherrard and Kallistos Ware. London: Faber \& Faber, 1979, vol. I, pp. 31-34.

25. Philip Schaff, and Henry Wace, eds. The Seven Ecumenical Councils, The Nicene and Post-Nicene Fathers, Second Series. Edinburgh: T\&T Clark, 1886, (reprinted 1997), pp. 356-408.

26. Joseph Ratzinger. "Theological Problems of Church Music." In Crux et Cithara: Selected Essays on Liturgy and Sacred Music. Edited by Robert Skeris. Alötting: A. Copperath, 1983, pp. 214-22.

27. Niceta of Remesiana. "On the Benefit of Psalmody." In Strunk's Source Readings in Music History. Edited by James McKinnon. New York: Norton, 1998, vol. 2.

28. Ephrem the Syrian. Hymns on Paradise. Translated by Sebastian Brock. Crestwood: St Vladimir's Seminary Press, 1990.

29. James McKinnon. "Desert Monasticism and the Late Fourth-Century Psalmodic Movement." Music \& Letters 75 (1994): 505-19.

30. Nikiphoros the Monk. "On Watchfulness and the Guarding of the Heart." In The Philokalia. Translated and Edited by G.E.H. Palmer, Philip Sherrard and Kallistos Ware. London: Faber \& Faber, 1995, vol. 4, pp. 194-206. 
31. Alexander Lingas. "Hesychasm and Psalmody." In Mount Athos and Byzantine Monasticism. Edited by Anthony Bryer and Mary Cunningham. Aldershot: Variorum, 1996, pp. 155-68.

32. Thaisia of Leushino. Letters to a Beginner: On Giving One's Life to God. Wildwood: St. Xenia Skete, 2005.

33. Ivan Lipaev. "Untitled concert review." Russkaya Muzykal'naya Gazeta 4 (1898): 400, quoted in Vladimir Morosan. Choral Performance in Pre-Revolutionary Russia. Ann Arbor: UMI Research Press, 1986, p. 221.

34. Alexander Kastal'sky. "My Musical Career and Thoughts on Church Music." Musical Quarterly 11 (1925): 231-47.

35. John Dillenberger. A Theology of Artistic Sensibilities. London: SCM Press, 1987.

36. Richard Viladesau. Theology and the Arts. New York: Paulist Press, 2000.

(C) 2015 by the author; licensee MDPI, Basel, Switzerland. This article is an open access article distributed under the terms and conditions of the Creative Commons Attribution license (http://creativecommons.org/licenses/by/4.0/). 